\title{
The Communication of Intangible Cultural Heritage of Museum from the Space Perspective
}

\author{
Mei XIE ${ }^{1,}$, Rong $\mathrm{ZHU}^{2, *}$ \\ ${ }^{1}$ Mei Xie, professor of School of Political Science and Public Administration in \\ University of Electronic Science and Technology of China, Chongqing, China \\ ${ }^{2}$ Rong Zhu, graduate student of Journalism and Communication major in \\ University of Electronic Science and Technology of China, Linxia, Gansu, China \\ Xiemei001@163.com,xiguazhandui@163.com \\ *Rong Zhu
}

Key words: space; museums; intangible cultural heritage; communication

\begin{abstract}
From the perspective of natural space, museum is a kind of "materialized" intangible cultural heritage and the collection is a medium to express its cultural connotation; from the perspective of spiritual space, the symbolic and the public characters of the museum make it a spatial symbol of intangible cultural heritage, and by means of its own visit ceremony, the visitors' existing cultural identity have been consolidated; from the perspective of social space, museum reflects the evolution of social relationships, and is an important symbolic presence and culture landscape. From the new dimension of space, this paper reexamines that how the intangible cultural heritage spread, transformed and utilized in space, and further explore the role and influence of museum in the dissemination of the intangible cultural heritage.
\end{abstract}

\section{Introduction}

Since 1980s, with the huge impact of the economic and cultural globalization on traditional cultural heritage, especially on folk cultural heritage, and the consensus that the right to maintain the cultural uniqueness is the basic human right [1], intangible cultural heritage began to draw attention.

In China, researches on intangible cultural heritage started late. The achievements of the intangible cultural heritage studies can be summarized as following: first, the knowledge on the concept and the connotations of the intangible cultural heritage; second, the discussion on the current background of intangible cultural heritage protection; third, the understanding of characteristics of the intangible cultural heritage; fourth, the investigation on the classification of the intangible cultural heritage; fifth, the investigation about the protection methods of the intangible cultural heritage. Among the existing researches, from the perspective of space, the studies concentrated on the display design and the application new media technology, there are very few investigations regard the space of museum as the materialized cultural expression, symbolic presence and expression of social relationships.

Museum has to abandon the traditional idea of "communicator-oriented", because of the emergence of new technology, new media, new formats and new ideas, and turns to "visitor-oriented". During this transformation, the introduction of "space" can provide an important theoretical support. "From the perspective of social sciences, space is not merely a material existence, but also a phenomenon about culture, politics and psychology. The configuration and the experience of space, and the way of forming the conception of space, shapes personal life and social relationships" [2]. From the perspective of the transformation and utilization of cultural resources, museum has the need and the advantage of "space orientation" in disseminating intangible cultural heritage. 


\section{Museum and Intangible Cultural Heritage Communication}

In the "Notification of State Council: on Strengthening the Protection of the Cultural Heritage", "intangible cultural heritage refers to the forms of culture, existing intangibly, closely related to people's life and passing down from generation to generation, including oral legend, traditional performing arts, folk activities, rituals and festivals, folk traditional knowledge and practices about nature and universe, traditional craftsmanship, and the cultural spaces which are closely related to the traditional cultural manifestations mentioned above” [3]. In terms of cultural space, architectural space and human beings are the most important elements of it. Once original cultural space disappears, the intangible cultural heritage will become unsustainable and the preserved tangible cultural heritage will also decline [4].

As the carrier and space of history and culture, museum has an inextricably link with the protection of intangible cultural heritage. In the process of collecting, protecting, and researching the material heritage, scholars finds that many cultural achievements cannot be included into the tangible heritage. Therefore, modern museology gradually brings the intangible cultural heritage into its research scope, and museum also be regarded as an important way in protecting the intangible cultural heritage [5]. During the establishment of "Intangible Cultural Heritage Protection Convention", UNESCO makes a particular explanation of the "safeguard" of the intangible cultural heritage. Safeguard of intangible cultural heritage means "take measures to ensure the survivability of the intangible cultural heritage, which include the identification, record, preservation, promotion, dissemination and revival of the intangible cultural heritage" [6].

Collection, conservation, research, dissemination and display on material or immaterial evidence of human and human environment, all these functions make museum has a unique advantage on the protection and development of the intangible cultural heritage. First, the advantage of talent and research. Museums has accumulated a wide range of professionals. They not only bear the work of the tangible cultural heritage of the museum, but have done much research on the intangible cultural heritage. Second, the advantage of protection, preservation and collection. Museum has stable and safe equipment and facilities with various temperature conditions. Third, the advantage of display. At present, most museums in China have fixed place to for exhibition, and the professionals related to the display design [7].

\section{Communication of the Intangible Cultural Heritage in the Context of THE Museum Space}

Lefebvre hold that "space is a product of society." which is the product of social relationships [8]. Museum is a condensed version of "human history". It embodies human activities in the process of human development and reflects the changes of social relations. The conservation and dissemination of the intangible cultural heritage are parts of social development.

Lefebvre classifies space into three types: natural space, spiritual space and social space. Natural space, referring to physical space, which can be accurately measured and depicted in a certain range. Spiritual space is human beings' concepts and imagination about space, such as people's consciousness, symbols, signs. Social space refers to the space that a person created in real life or social life. Not only things but also relations can constitute the social space.

\section{Natural Space: the Combination of the Abstraction of the Intangible Cultural Heritage and the Concretization of Museum Space}

Museum is the ocean of object, which is a visual and tangible form of culture; while the content of the intangible cultural heritage is intangible. Thus, the perception, protection and communication of the intangible cultural heritage is a process of materialization. From intangible to tangible, this process is depended on the unification of the intangible cultural heritage and the museum [9], that is the integration of the abstract and the concrete.

As for the materialized display, physical collections can bring the most intuitive feelings to the visitors. Panels are integrated into the interpretation and explanation of the researchers. Models and appliance can reveal many cultural connotations with the materialized forms. The new media is the 
digital media which can provide presentations or interactivity by using documentaries, games, animation and other forms to strengthen the visitors' understanding of the intangible cultural heritage.

As for the non-materialized display, traditional performances include drama, dance, stage play, oral legends, folk art, etc.. Lived show can make the scene emotional and interactive, which is the most intuitive and authentic way to embody the intangible cultural heritage.

In the display of intangible cultural heritage, environment, as a media, plays a crucial role. It can make the visitors generate a feeling of "immersion" to the contents of the display. A realistic restoration of a historical scenes can create a immersive effect piercing time and space during the communication [10].

With the continuous development of digital technology, the communication of the intangible cultural heritage can also be achieved by digital imaging, but the drawbacks of digital technology is that it freezes the "living state" of the intangible cultural heritage into history. Visitors can only learn the intangible cultural heritage in a fixed historical period.

\section{Spiritual Space: the Aesthetic Experience and Cultural Identity Brought by Museum}

Based on the technological and economic development of the modern society, to build a modern and high-tech museum is not a problem. What is more critical is to integrate an experience into modern equipment, facilities and services, an enjoyable experience to visit, which is the key to the construction and the management innovation of contemporary museum. This enjoyable experience requires museum managers to focus on the needs of the visitors and circumstances and have to assimilate humane, harmonious, emotional and other factors into the environment, systems, services and atmosphere, etc... The museum managers should not only focus on the carrier, that is the material manifestation, but continue to tap the cultural connotation in the evolution of the intangible cultural heritage development and try their best to spread the sustainable development of the culture to the audience as much as possible, when record all these changes.

In Culture and Society (1958), British Marxist cultural theorist Raymond Williams attempts to combine "lived" with "culture". He believes that "a culture can never be reduced as an artifact when it is being lived" [11]. The culture that is being lived by people is abundant. Williams used the term "lived culture" [12] officially in The Long Revolution published in 1961. He points out that:"Even the broadest definition of culture also has to clarify the three levels of culture. The first level is the lived culture under the particular time and space, which is understood only by the people who live in that times; the second level is the record of various cultural forms, including art to the vast majority of daily events, namely a culture of an era; the third level is the culture of selective tradition, aiming at linking the lived culture with the culture of a certain age” [13]. Williams first proposed and explicate the cultural term "lived culture", which has a broad impact on cultural studies and shows the focus and the basic trend of contemporary cultural research.

From the perspective of cultural identity, museum make people break away from the original social structure temporarily and get into and through a series of ritual activities, and then rejoin the social structure. The subject who experience this ritual, whether individual or groups, will get stable or repeated cultural identity. When people return to the order of the daily life, social identity and status often have promoted, and the existing cultural identity also be consolidated. For any visitor, no matter what kind of ritual, it will affect the construction and maintenance cultural identity of individual or groups ultimately.

\section{Social Space: the Society Turn of Museums' Dissemination of the Intangible Cultural Heritage}

The "Quebec Declaration" (1984) states the: "Museum is or should be socially owned and the best tools to complete the preparation of social reform.” The intangible cultural heritage, in the field of museum, is often regarded as a social phenomenon of a certain period of time, and its display is also linearized with quality of expression. Definitely, the social existential significance this approach bringing to the intangible cultural heritage is not be ignored, but whether the intangible cultural heritage can only put themselves in the shackles of history? This question makes the 
museum consider the society turn of the non-material cultural resources in the dissemination of the intangible cultural heritage.

First, to actively absorb the concept of the museum with continuous development. "New museology", emerged in the 1970s, focuses on the needs of the community, taking museum as a symbol of social culture, paying attention to the interaction and coordination of museum with social culture, and also promoting the protection of the integrity of cultural heritage, which means to preserve the heritage with related natural and cultural environment [14]. Indigenous curation is one way of museum management which is advocated recently by western scholars. In indigenous curation, the subject of the management is community members. For the displyed cultural heritage of the community, the members of the community have the right to interpretation, and to participate in the exhibition and protection. This model can guarantee the "authenticity" and "integrity" of the intangible cultural heritage [15].

Second, to build bridges between the "lived carrier" and the society. The inheritors of the intangible cultural heritage are the "lived carrier" of the intangible cultural heritage, which plays an irreplaceable role in the protection and development of the intangible cultural heritage. However, the inheritance of intangible cultural heritage need time to practice with words and actions, and this slow process can easily be broken by the fast-paced lifestyle. In view of this situation, museum should exploit the advantage of its platform, enhance the communication between the inheritor of the intangible cultural heritage with government, cultural organizations, and the public, so as to promote the development of inheritor of the intangible cultural heritage physically and spiritually, contribute to the government's decision-making concerning about the inheritors and the cause of the intangible cultural heritage, and to enhance the public understanding to the inheritors [16].

In addition, in the context of modernity, museum's function gradually spread from cultural heritage to cultural consumption. When the trend of consumerism and popular culture combine, the urban space produced by museum would show a distinct color of consumption culture, which is mainly reflected in the culture reproduction and consumerism transformation of museum's form. The extension and transformation of museum's function has become a reality abroad, and for the society turn of the intangible cultural heritage, this conversion will undoubtedly have a positive impact and significance.

\section{Summary}

In the new era, we need to redefine the museum and the intangible cultural heritage. Also space need more pondering. New urban sociology emphasizes the binary relationship between social and space:"On the one hand, within the limits of society structure, human act in certain spaces; on the other hand, human beings can create and change space to express their needs and desires" [17]. Beyond museum and collection, space theory adds a new dimension to the research of intangible cultural heritage.

Maintaining cultural diversity, seeking cultural identity and enhancing the sense of national history are the real and urgent requirements of various countries in the process of economic, technological and cultural globalization. Museum, as a witness of human and human environment by collection, conservation, study, dissemination and display, must be duty-bound to take up the task to protect and communicate the intangible cultural heritage and complete the historic mission.

Under the grand narrative background of intangible cultural heritage protection, from exploring the fundamental value of protect and intangible cultural heritage, museum actively participating in the dissemination of intangible cultural heritage is an inescapable, significant and developmental task. As the deepening awareness of museum protecting and promoting intangible cultural heritage, the measures to protect and various intangible cultural heritages will continue to emerge.

\section{Acknowledgment}

This article was financially supported by "model research of museology resources of conversion utilization” for National Social Science Fund Project in 2014 (Project Number: 14BGL162). 


\section{References}

[1]Niec, H. Cultural Rights and Wrongs, Paris: UNESCO Publishing,1998.

[2]Su shangfeng. Three Disputes of Spatial Theory and "Space Turn”[J], The Journal of Humanities, 2008, (4):23-29.

[3]Notification of State Council: on Strengthening the Protection of the Cultural Heritage. 2005:42.

[4]Li li\&Hua chen. Eco-museum: the New Technology of Intangible Cultural Heritage Conservation[J]. Urban Development Studies, 2009, (1):86.

[5] [14] Wang xin. The Construction of Museum from the Perspective of Intangible Cultural Heritage Protection[C]. Proceedings of Chinese Annual Meeting of Anthropology of Art, 2012:184.

[6] Deacon, Harriet, etc.. The Subtle Power of Intangible Heritage[M], South Africa: HSRC PubLicers 2004, 5.

[7]Zhao dongju. The Interaction Between Museum and Intangible Cultural Heritage[J]. Guangxi Ethnic Studies, 2006, (2):6.

[8]Henri Lefebvre. The Production of Space [M]. Wiley-Blackwell. 1991:146.

[9]Han yang. The Discussion on the Problems of Intangible Cultural Heritage and Museum[J]. Museum Research. 2006, (3):73.

[10]Yang min. Discussion on the Intangible Cultural Heritage Display of Contemporary Museum. M.A. thesis. China Academy of Art, 2014,5.

[11]Raymond Williams. Culture and Society: 1780-1950[M]. Anchor Books Doubleday \& Company, Inc. 1960: 343.

[12]Raymond Williams. Culture [M]. Glasgow: Collins, 1981: 11.

[13]Raymond Williams. The Long Revolution [M]. Parthian, 2011: 70.

[15]Jiang nan. Intangible Cultural Heritage and Museum. M.A.thesis, Zhejiang University. 2011.5

[16]Chen qian. The Role of Museums In The Protection of Intangible Cultural Heritage. M.A.thesis, Zhengzhou University. 2013.5

[17]He xuesong. Spatial Turn in Social Theories[J], Society, 2006, (2): 34-48. 